\title{
THE ROLE OF END CHILD PROSTITUTION, CHILD PORNOGRAPHY AND TRAFFICKING OF CHILDREN FOR SEXUAL PURPOSES (ECPAT) IN ADDRESSING THE CHILD'S COMMERCIAL SEXUAL EXPLOITATION IN INDONESIA (2011 - 2015)
}

\author{
John Benedicktus Meninu Nalele \\ International Relations, Universitas Kristen Indonesia, Jakarta, Indonesia \\ yohanesbenedicktus@gmail.com
}

\begin{abstract}
Commercial sexual exploitation of children is a social problem that has several categories. This issue is scattered in many countries, especially in Asian countries. Child's commercial sexual exploitation or eksploitasi seksual komersial anak (ESKA) can ruin the future of the children who are victims, of which they are the successors of the nation. Childhood should be filled by playing and learning but changing with the dark. The role of government as the supreme authority of a country in overcoming the problem of ESKA looks not maximized. The purpose of this research is to find out the role of international organizations in addressing the ESKA problem. International organizations, in this case, are ECPAT or End Child Prostitution, child pornographic grapy, and Trafficking of Children for Sexual Purposes. How are their efforts and roles in overcoming ESKA and its cooperation with the Indonesian government, obstacles, and challenges faced? The benefits of this journal are useful in the development of International Relations, especially those involving the role of international organizations in addressing the problems of ESKA. The method used is descriptive - qualitative, where this method illustrates and analyzes the role of ECPAT as an international organization in addressing the ESKA in Indonesia (2011 - 2015).
\end{abstract}

Keywords: ESKA, international organization, ECPAT, Constructivism, Government of Indonesia

DOI: 10.33541/sp.v20i1.1435

Sociae Polites : Majalah IImiah Sosial Politik

Faculty of Social and Political Science, Universitas Kristen Indonesia

ISSN 1410-3745 print/ ISSN 2620-4975 online

Volume 20, Number 1 (January - June 2019)

Pages 1-19 


\section{Introduction}

\subsection{Background}

Children are the successor generation of the nation and are an invaluable asset in the world. According to the Children's Rights convention of article 1, the child is any person under the age of 18, except under the law stipulates that the adulthood is achieved earlier (Indonesia K. N., 2008). Therefore, sexual acts performed in children under 18 years of age are evil and must be dealt with immediately. Commercial Sexual Exploitation of Children (ESKA) is a severe breach of the rights of the child and is an insult to our collective dignity. The Declaration and Action Agenda for the opposition to commercial sexual exploitation The child defines ESKA as "sexual violence by adults and the granting of rewards in the form of cash or goods against children, or persons one third, or other persons" (ECPAT, 2016).

Commercial Sexual Exploitation of Children (ESKA) is one of the other forms of human trafficking. It is a severe breach of the rights of children where the child is treated as a sexual object and as a commercial object using coercion and violence that leads to forms of forced labor and Modern slavery (ECPAT International, 2016). UNICEF estimates that more than 2 million children fall victim to ESKA annually (U. S Department of State, 2011). Children of the ESKA victims experience a range of severe emotional, psychological, and physical impacts.

The Era of globalization today also affects the dynamics in the world of international relations - issues that develop not only about war and borders but the problem of low politics. Health, human rights, prosperity, hunger, and other humanitarian-related ones are more interesting to note, one of which is the child's commercial sexual exploitation. Human trafficking, especially related to children, is the third-largest business after drug trafficking and trafficking in weapons. Human trafficking is a profitable business because it is "low risk, expandable, reusable and resellable" (Konrad, 2002:5).

The United States Department of State annually releases a human trafficking report that categorizes countries into tiers based on the extent to which government actions are to combat human trafficking. Countries with the highest level following the minimum trade protection legislation standard for the elimination of trades placed in tier 1. States that have done "meaningful efforts" to meet the rules set in level 2 and countries that do not make meaningful efforts to combat human trafficking placed in level 3. In the year 2016, Indonesia at tier 2. It means that Indonesia is a proactive country in the business of tackling the trafficking of children.

The role of the country in the function of protection against its people is increasingly more substantial; therefore, the state through the government must be in cooperation with the non-governmental organization to co-fight the exploitation of children. One of them is ECPAT or End Child Prostitution, child pornography, And Trafficking Of Children For Sexual Purposes (ECPAT). The power of the ECPAT movement based on local, national, and international activities. At the same time, international activities conducted and/or promoted and/or assisted by the Secretariat provide strength and credibility to individual groups. By working together, this ECPAT actor provides increased status of movement and authority in international circles. ECPAT movement is the main actor in combating CSEC (The Commercial Sexual Study of Children). 
Based on the commitment to work together against the commercial sexual exploitation of Children (ESKA), in 2000 was held a national consultation to form a network organization or coalition to eliminate child sex trafficking, child prostitution, child pornography, child sex tourism, and child marriage. National meeting on the existence of cooperation with Indonesia through international ECPAT network in Indonesia, namely National Coalition for the Elimination of Sexual commercial exploitation of children (Konas Peska). Indonesia officially joined the International ECPAT Network in 2005.

\subsection{Research Question}

What is the role of ECPAT in handling the ESKA in Indonesia period 2010 to $2015 ?$

\section{Literature Review}

The study of International Relations is a study dominated by Western thinkers (Rafia 2015). IR is a study that covers the international community or global system. According to Karen MINGST: International Relations is a study that learns about interactions among various actors participating in international politics, covering countries, international organizations, non-governmental organizations, sub-national unity such as bureaucracy and local governance, and individuals (Mingst 1999, 2).

The phenomenon that will be the author of meticulous is the role of ECPAT as an international non-governmental organization focusing on the work plan to cope with the case of commercial sexual exploitation of children occurring in Indonesia where the period of Elitian pen from 2011 until the year 2015. In this study, the authors will use relevant theories to be able to describe this phenomenon as well.

To explain the ECPAT phenomenon in his efforts to tackle the ESKA problem, the authors use the role theory of international organizations. The international organization, in a broad sense, primarily includes not only the international public organization but also private international organizations. Such international organizations include regional organizations and sub-regional organizations.

The international organization is a pattern of cooperation that crosses the boundaries of the country. Based on the bright and complete organizational structure and expected or projected to take place and implement its function continuously to strive to achieve the fundamental objectives and mutually agreed, both between government and the government and among other non-governmental groups in different countries. (Rudy 2009, 3).

ECPAT, as an organization consisting of many individuals, performs its role as an organization that engages in handling the ESKA. They play a position as a nongovernmental organization that assists the government of a country in addressing the ESKA issues that occur. In his role in International Relations, a person or individual usually commits a group action. Similarly, ECPAT cannot move together with the government of a country because it looks at the importance of the sovereignty of the country. ECPAT must cooperate with the government so that they can role-play according to their objectives.

All international organizations have an organizational structure to achieve their objectives. If those structures have already been functioning, then the organization has 
played a particular role. Thus, the part can get considered as a new function in the pursuit of community goals. In line with countries, international organizations can undertake and have several important roles:

1. Provide a means of cooperation among countries in various fields, where the partnership gives a profit for the majority of the entire membership. Besides, to be a place where decisions about cooperation made, international organizations also provide administrative devices to translate those decisions into action.

2. Provide various communication lines between the governments of the countries, so that it can be explored and will facilitate access when problems arise (Bennet 1995, 3).

The role of international organizations can be described as individuals residing in a global community environment. As a member of the international community, international organizations must be subject to mutually agreed rules. Besides, each member performs activities to achieve his goals.

The role of international organizations aimed at organizational contributions within broader regulations, other than the troubleshooter. The part of international organizations divided into three categories:

1. International organization as a collective legitimacy for the activities of the organization and/or members were individual.

2. International organization as a determinant of the global agenda.

3. International organizations as containers or instruments for inter-member coalitions or coordination of policy intergovernmental as mechanisms for determining the global character and power structures (Bennet 1995, 8).

The author also uses a constructivism perspective to try to parse the ECPAT phenomenon. According to Reus-Smit (2001, 209), constructivism mainly emerged as a form of reaction to the failure of the dominant tradition that existed earlier in international relations in predicting or understanding various systematic transformations that drastically changed the world's order. In this regard, constructivism considers that the dominance of the existence of traditional traditions in its development is not able to explain changes related to the phenomenon in international relations.

At least two fundamental ideas of constructivism are relevant to the study of international relation. Firstly, the belief that shared plans is more determined the structures that unite humankind than in the strength of the material and secondly, the notion that shared ideas more identify the identities and interests of the actors than on natural factors. That is, the actions of each actor not solely determined by their motives, reasons, and interests; But more formed by the interaction between individuals in the surrounding environment, such as social structure, politics, economics, culture, and so forth (Hermawan 2007).

In contrast to mainstream perspectives such as realism and liberalism put a strong emphasis on the perpetrators and the various patterns of relationship between them, constructivism looks at the multiple dimensions of the construction of the idea as a result of interaction among actors. Constructivism theorist believes a variety of buildings of collective schemes are products of various interactions of actors in the realm of empirical (Pramono \& Purnowo 2010, 15).

Constructivism has brought social, historical, and normative aspects to the realm of debate in international relations. Constructivism helped revive the normative hypothesis by demonstrating the power of ideas, norms, and values in shaping world 
politics. They have shown how international standards develop, how beliefs and values are present to form political action, how arguments and discourse result in a condition, and how to create agents and agencies, all in a contradictory way from the hopes of materialist and rationalist theory (Reus-Smit 2001, 227). This alternate perspective has emphasized the importance of the influence of identity, culture, and norms in the establishment of international political systems and structures that were previously never alluded to by classical perspectives in international relations.

Unlike the neo-realists who consider the international structure to have a direct influence on the behavior of the state, this structure also directs actors to redefine their interests and identity in the interaction process. This ideational structure forms the way actors define who they are, their goals, and the roles they believe they should do (ambarsari 2017).

Seeing the main focus of constructivism is the idea or idea that was born from various interactions of international relations actors. Researchers know the emergence of NGOs such as ECPAT will create new ideas. Constructivism tries to understand NGOs like ECPAT as a new container that will bring new concepts or ideas through their activities. Advocacy to the government for renewal of legislation, cooperation in various fields, and socialization to the community is an activity undertaken by ECPAT.

Expected by using qualitative methods and relevant theories, researchers can analyze the role of ECPAT in addressing the case of commercial sexual exploitation of children in Indonesia from 2011 to 2015. ECPAT has been assisting and working with the Indonesian government so that instances of child sexual abuse in Indonesia can be immediately suppressed and reduced. ECPAT held a campaign and protection against the victims of child sexual abuse and was active in counseling through education so that children could get spared from an irresponsible person.

With the activities of ECPAT active activities can strengthen the implementation of legal aid, rehabilitation, and psychosocial services to children who are victims of sexual exploitation, enhancing the implementation of legal support, repair, and psychosocial services to children who are victims of sexual exploitation, build public awareness to remove the demand for child sexual exploitation and encourage the creation of a mechanism that gets integrated with human rights in enhancing the optional implementation of the Child Rights Convention Protocol on Child Sales, child prostitution and child pornography.

\section{Research Method}

The methodology is the process, principle, and procedure that we use to approach the problem and seek answers (Bogdan \& Taylor, 1975, 84). Another expression of the methodology is a general approach to reviewing research topics (Silverman, 1993). The method used in this study is a qualitative method aimed at generating hypotheses from field research (Mulyana, 2001, 145). The qualitative approach is more based on the phenomenological philosophy that prioritizes the understanding (verstehen). This method is to understand and interpret the meaning of interaction of human behavior in certain situations according to a research perspective. Qualitative methods, often using participatory observation techniques, interviews, and documentation (Usman \& Akbar 1996, 81).

According to H.B. Sutopo $(2002,35)$, qualitative research involves ontological activities. The Data collected is primarily word-words, sentences, or images that have 
more meaning than just numbers. Researchers emphasized records describing the actual situation to support data presentation. According to Kirk and Miller quoted Lexy J. Moleong $(2004,4)$ defines, "qualitative research is a certain tradition in social sciences that fundamentally depends on human observation both in its region and in its terminology."

This research is a descriptive that is supported by qualitative data, which is the process of research that is precisely describing the nature of an individual, circumstance, specific symptoms or groups, and the relationship of a trait with other symptoms. While in Gay opinion quoted Consuelo G Sevilla $(1993,71)$ who defines, "a descriptive research methodology as an activity that includes data collection to test hypotheses or answer questions that concern the situation at the time that is running from the subject of a study."

The study aims to describe the roles performed by End Child Prostitution, Child pornography, and Trafficking of Children for Sexual Purposes (ECPAT) in an attempt to address the child's commercial sexual exploitation (ESKA) in Indonesia from 2011 to 2015. How its implementation and cooperation with the Government of Indonesia in the implementation of its role.

The data source used in this research is the premier data source, which is the data obtained directly from the sources involved in the phenomenon to get researched. According to H.B. Sutopo $(2002,49)$ says that in qualitative research, the data sources can be human (informant), events or activities, places or locations, objects, various images, recordings, documents, and archives.

According to Hasan $(2002,82)$, primary data is data that is obtained or collected directly in the field by the person who has the research or in question that requires it. The primary data at the source of the informant is an individual or a person, like interview results conducted by the researcher. The Data obtained is an in-depth view of the individual involved directly in a studied phenomenon. Researchers will have an interview with Mr. Andy Ardian, who is the Manager of the ECPAT Indonesia Program, which will be the main informant.

Secondary data is data obtained or gathered by people researching existing sources (Hasan, 2002, 58). This data used to support the primary information collected from the library materials, literature, previous research, books, and so forth. Data collecting. The data collection techniques with interviews and literature study.

\section{Results and discussion}

\subsection{ECPAT Overview}

ECPAT International is a network of civil society organizations and civil society coalitions that are formed based on shared objectives to end the sexual exploitation of children around the world. ECPAT conducts innovative research to build a collective understanding of what will get done to stop the sexual exploitation of children. Together with members and partners, they coordinate evidence-based advocacy at all levels to strengthen the judicial system and national protection and increase investment in the war against sexual exploitation of children (ECPAT Indonesia 2016). In 1996, the ECPAT Network, in collaboration with UNICEF and the NGO Group for the Convention on the Rights of the child, organized the First World Congress to oppose commercial sexual exploitation of Children (ESKA) in Stockholm, Sweden. 
In Congress, a total of 122 countries adopted the Stockholm Declaration and Action Agenda (action Agenda) requesting countries, all sectors of society, as well as national, regional, and international organizations to take a step against ESKA (ECPAT, 1996). In particular, the action Agenda asked the country to develop a national action plan to oppose ESKA and to implement the action Agenda in six areas, namely: coordination, cooperation, prevention, protection, recovery and reintegration, and participation of children. The National Action plan provides an opportunity for state institutions and childcare institutions to cooperate in formulating various national strategies to abolish the ESKA and promote the rights of children.

At the first World Congress in Stockholm, Sweden, several NGO representatives from Indonesia were attracted by the issue of child sexual exploitation. After the Congress, representatives of NGOs were present, providing information and meeting. There are about 20 institutions that focus on children and see that the ESKA issue is essential. They wanted to form an institution that pioneered and coordinated the handling of the matter.

In the year 2002, KONAS PESKA formed the National Coalition for the elimination of commercial sexual exploitation of children. The name used because, at that time, the institute was still not certified by the International Network ECPAT. In the year 2005, KONAS PESKA was officially admitted by ECPAT International into affiliate Group, namely, to become a member or network ECPAT in Indonesia. In 2010 because the progress in Indonesia is particularly good, then the status of the member was promoted to Nation group, and in 2012 is allowed TO USE the name or logo of international ECPAT. This marked the abandonment of KONAS PESKA to ECPAT Indonesia (Andy ardian 2017).

\subsection{ECPAT Indonesia}

ECPAT Indonesia is a national network organization working together in more than 20 organizations in 11 provinces in Indonesia to oppose the child's commercial sexual exploitation. ESKA includes child sex trafficking, child prostitution, child pornography, child sex tourism, and in some cases, child marriage (ECPAT Indonesia 2016).

ECPAT Indonesia is committed to strengthening national action in efforts to prevent and eliminate the ESKA in Indonesia by establishing collaboration with key cross-sector parties such as civil society organizations, academics, government agencies, the private sector, international agencies, and other relevant sectors (ECPAT Indonesia 2016).

ECPAT Indonesia is part of ECPAT International, a global network that works to oppose ESKA with members of more than 84 groups in more than 75 countries around the world. As part of the worldwide web, ECPAT Indonesia engages in the implementation of various initiatives on crucial issues both at the national and regional levels. Members must follow the involvement of ECPAT Indonesia at the provincial level on behalf of the National Network (ECPAT Internasional 2016).

ECPAT Indonesia has a vision and mission adopted from international ECPAT values, such as the following:

- Vision: Every child of Indonesia is free and protected from any form of commercial sexual exploitation and fulfillment of fundamental rights of children guaranteed by all communities and governments. 
- Mission:

- Mission to Members:

Build commitment and reliable cooperation, adequate capacity, and extensive network in every effort to wind the ESKA.

- Mission to society:

Build and raise awareness, caring, critical attitudes, and participation of the wider community, children, and young people to together combat the ESKA problem.

- Mission to the Government:

Encouraging the government to commit and make efforts - concrete efforts are both administratively and legally in combating ESKA in Indonesia.

\subsection{ECPAT Indonesia's role with the Indonesian government}

ECPAT Indonesia has a cooperation with the Government of Indonesia to handle ESKA. The role includes various activities conducted together with the government to the Indonesian people as follows:

- Regional Seminar

This regional seminar discusses the eradication of child sexual exploitation. This activity is the result of ECPAT Indonesia's cooperation with the Ministry of Women Empowerment and child protection. The focus of the seminar is on the framework of law and international cooperation.

The workshop, held in 2011, organized the implementation of the same legal framework and established international collaboration with the delegates in attendance. The seminar attended delegates from Southeast Asian countries, Timor Leste, France, and the United States (ECPAT Indonesia 2011, 5).

This seminar is one of ECPAT's roles in determining the international agenda. It hoped that the cooperation of the delegates present could establish a proper legal framework in addressing the ESKA case. KPPPA, as a government agency that oversees the protection of children, feels the need to contribute to this activity. In addition to the new information that could get obtained, they can also define new policies.

- Enhancement of criminal trafficking and child sexual exploitation prevention education

The program supported by the Ministry of Education and Culture (KEMENDIKBUD) is one of the applications for increasing participation of young people. This program chooses South Tangerang as a project site that includes several activities during the program, namely: mapping problems and prevention actions of TPPO and ESA; Development of TPPO and ESA authentication models; Socialization on the prevention of TPPO and ESA to the vast society and promotion of young people's participation in prevention; and community training on the prevention of TPPO and ESA (ECPAT Indonesia 2012, 4).

ECPAT Indonesia conducted the same program again in 2013. Kemendikbud still supports the same program, this time located in the East Jakarta area. This program aims to provide information to the surrounding 
society about the dangers of trading people who can occur in the nearby environment and also provide information on how to report when viewing the case of the ESA in the neighborhood (ECPAT Indonesia 2013, 6).

This program divided into three sections, and the first is the Forum Group Discussion (FGD) held on 9 November 2013 to explain and discuss the problem of people's trading and the way of prevention. Secondly, legal training to improve the understanding of the society in the handling of the trade case of people executed on 29 November 2013. Third, implementing the socialization of TPPO and ESA prevention in East Jakarta on 19 December 2103 in hopes of being able to be useful to the community in the efforts to prevent people from trafficking and increase awareness of the traffic of people who can occur (ECPAT Indonesia 2013, 6).

- Strengthening the implementation of legal aid, rehabilitation and psychosocial

In this program, ECPAT Indonesia cooperates with the Supreme Court, attorney general, police headquarters, and PERADI. MOU with the law enforcement institution characterizes the seriousness of this partnership. Activities conducted include providing direct legal assistance or referral assistance; Organizing various training, education, mentoring and sharing of information with partner institutions, and conducting psychosocial and rehabilitation training.

The program also generates an increase in the institutions or organizations that have an interest in providing legal aid to victims of child sexual exploitation. ECPAT Indonesia also has a model of lawful handling of the victims of sexual exploitation and used as a learning institution for civil society organizations. Rehabilitation and psychosocial services are getting better (ECPAT Indonesia, 2016).

- Research

ECPAT also researches in collaboration with the Ministry of Social Affairs. A study conducted on sexual offenders and children can become doers sexually. Research to design a system with the Center for Financial Transaction Inspection and Analysis (PPATK). The system is intent is to track the transactions concerned with child sexual exploitation (Andy Ardian 2017).

\subsection{ECPAT role as an international organization}

ECPAT, as an international organization focusing on the handling of ESKA, certainly has a global agenda that can affect the processing of ESKA in Indonesia. Besides, ECPAT also has functioned as a container and instrument in addressing the problems of the community, especially Indonesia. Researchers display data tied to the role of ECPAT as a non-governmental international organization in

ECPAT Indonesia has implemented several programs during 2011 to fulfill its objectives following its vision and mission. The following are activities that have been conducted by ECPAT Indonesia during the year 2011:

- Developing investigative modules, monitoring and reporting the ESKA case 
The first program in the year 2011 is the development of modules conducted on this program, namely formulating the investigation module, monitoring and reporting the case of ESKA in Indonesia, and dissemination of a draft module for National Coalition members to input. This program produces a unique formulation of modules for civil society institutions in Indonesia (ECPAT Indonesia 2011, 4).

- Overcoming the trafficked of children and adolescents for sexual purposes

The main activity of this trafficked program is advocating on the ratification of the Optional Protocol of the Rights of the Child Rights Convention on Children's Sales and child pornography (OPSC), the Child Research step (in cooperation with the University of Indonesia), to provide direct services for 104 victims of sex trafficking with the objective of 6 (six) major cities in Indonesia This Program produces several things, which are children research in cooperation with the University of Indonesia which has conducted, direct service for 104 victims of sex trafficking with the goal of 6 (six) cities in Indonesia has been sent, in addition to the more 200,000 petitions have been collected and submitted to the Ministry of Women Empowerment and child protection (ECPAT Indonesia 2011, 5).

- Media events about the Action Agenda report (Global monitoring on the status of THE action of ESKA in Indonesia)

The program carries out events attended by media, international institutions, local community organizations, academics, and other sectors. The results of this program socialized the global Monitoring Action Agenda report on the status of ESKA actions in Indonesia, as well as the publication of events in several mass media. This event intends to make the community better understand what ESKA (ECPAT Indonesia 2011, 6) is.

- Strengthen advocacy and youth participation to support the implementation of the National Action plan to eradicate people's trade and ESKA

Strengthen advocacy programs include advocacy and approach to relevant government bodies to promote the participation of young people as one of the strategic steps on the prevention of human trafficking also the child's commercial sexual exploitation. It formed a youth association that focuses on human trafficking and child sexual exploitation in 4 (four) cities in Indonesia (Jakarta, Medan, Batam, and Lampung). It facilitates youth programs to campaign about the trafficking of people and the commercial sexual exploitation of children to specific communities and groups. This program generates several dialogues and the audience with which the relevant government body produces several commitments supporting the participation of young people (ECPAT Indonesia 2011, 6).

ECPAT Indonesia has implemented several programs during 2012 to fulfill its objectives following its vision and mission. The following are activities conducted by ECPAT Indonesia during the year 2012 
- Strengthening advocacy and young people's participation: a support action in the implementation of the National Plan of Action for the elimination of trafficking in persons and commercial sexual exploitation of children.

This action is a pilot initiative to support the implementation of the National Action Plan (RAN) on the eradication of trafficking criminal acts and sexual exploitation period 2009-2014. This action focuses on advocating advocacy to encourage the government as part of a task force to tackle the issue seriously and to increase young people's participation in advocacy work and raising awareness among peer-to-peer groups and communities in general. The activities that are fully supported by the European Union involved four provinces. Namely; Yayasan Kusuma Buana (YKB) in DKI Jakarta, Child Advocacy Institute in Lampung (LADA), Our Setara Foundation in Batam (YSK), and the Center for Children's Studies and protection in Medan (PKPA).

This program designed to achieve 4 (four) objectives: the establishment of a National Coalition secretariat in Jakarta to conduct affective advocacy work at the national level; Affective advocacy of relevant government agencies and policymakers who generate political will and commitment in addressing the trafficking of persons and the sexual exploitation of children; The establishment of an active Youth association acts as supporting sub-groups of the National Action Plan task in the prevention and participation of children at the national and provincial level, and strengthening young people's associations to conduct community-based programs that work in the field of advocacy and awareness-raising among peer-group peers. In the implementation, various activities support the achievement of expected outcomes, such as audiences with provinciallevel task sub-groups, consultation meetings, workshops, seminars, training, talk show RADIO, and others (ECPAT Indonesia 2012, 3).

- They are strengthening ECPAT Indonesia in investigating, monitoring, and reporting cases of commercial sexual exploitation of children in Indonesia.

Mensen supports this ongoing program met een missie Netherlands (MM Netherlands) during 1 (one) year and, at the moment, has entered its fourth month of implementation. For three months, several activities in this program have been conducted, including preparation of the SOP Unit of legal services ECPAT Indonesia; Creation of leaflets and Factsheet; Socialization of ECPAT Indonesia's service unit; Mentoring several victims; Network meetings, and an audience effort with POLRI and several other related institutions (ECPAT Indonesia 2012, 5).

- Sexual Crime Conference of Children Online: Law Enforcement and Regional Cooperation.

The conference held a partnership between ECPAT Indonesia and the French Embassy and Terre des Hommes Netherlands. He was held from 29 to 30 October 2012, at Mercure Convention Center, Ancol - Jakarta.

The overall goal of the conference is to increase knowledge of the latest trends of sexual crimes against children online using communication and information technology and to review national and international 
legislation by law to build and strengthen the network and regional cooperation. The event was attended by more than 170 participants from 11 countries and presented 21 speakers from various countries and backgrounds, including presentations, discussions, exhibitions, social programs, and film screenings (ECPAT Indonesia 2012, 5).

- Research on reducing child trafficking in the working area of a child Fund.

The ongoing program that lasts for approximately six months and supported by the Child Fund works in 3 (three) research areas, namely: West Jakarta \& Tangerang; Central Java; and East Nusa Tenggara. The main activity of the program is collecting primary data from target respondents consisting of children who are victims/survivors of human trafficking with various objectives and collecting primary data from key stakeholders for the issue of each research area. The entire program aims to capture the child trade situation in the working area of the child Fund and to design a relevant intervention program on the issue that includes prevention, protection, and/or empowerment (ECPAT Indonesia 2012, 6).

- Dialogue of the national harmonization rules post ratification of the Optional Protocols of the Children's Rights Convention on child sales, child prostitution, and child pornography.

The full supported Event by ECPAT International was held on 19 December 2012 at the Ibis Arcadia Hotel in Jakarta with 3 (three) speakers from ECPAT International Ministries and jurists. This event bridged the initiatives of stakeholders in responding to the next step after the optional protocol ratification. It resulted in recommendations on the legislation related to pornography and sexual exploitation in Indonesia (ECPAT Indonesia 2012, 6).

- Advocacy of optional ratification protocols

The optional ratification of the protocols about child sales, child prostitution, and child pornography into law No. 11/2012, on 24 September 2012, is one of the successes of ECPAT Indonesia's advocacy work on the government. ECPAT Indonesia works in conjunction with several other influential organizations in advocacy, such as the European Union, Kinder Not Hilfe, Mensen meet Missie, The Body Shop, and so on (ECPAT Indonesia 2012, 8).

ECPAT Indonesia has implemented several programs during 2013 to fulfill its objectives following its vision and mission. The following are activities that have been conducted by ECPAT Indonesia during 2013:

- Strengthening internal management OF ECPAT Indonesia and Direct Services

This program is a series of activities to increase the capacity of the ECPAT Indonesia team in managerial affairs as well as strengthening the programs implemented by ECPAT in cooperation with the Body Shop Indonesia. ECPAT Indonesia held an internal meeting of the ECPAT team and meeting Board to discuss and formulate the ECPAT Indonesia program, as well as national deliberation (Munas) with ECPAT members throughout 
Indonesia conducted in January 2014. Besides, there is a web training, the manufacture of ECPAT SOP, also revitalizing the management undertaken by ECPAT consultant, Mr. Indrajit. ECPAT Indonesia also performs a direct service program conducted by ECPAT members, Bandungwangi, in the Jakarta area to increase the empowerment of children victims of sexual exploitation. There are two forms of programs implemented on this direct service,

Job-oriented special skills training in the form of initial orientation building, specialized skills training in the cosmetic and fashion industries facilitated by The Body Shop Indonesia, and on-job training at the cosmetics and fashion company.

Specialized skills training that oriented to the effort in the form of the practice of the standardizes conducted in the ways of building orientation, training, production and marketing management training, and production and marketing (ECPAT Indonesia 2013, 4).

- Strengthening ECPAT in investigating, monitoring and reporting cases of child commercial sexual exploitation in Indonesia

This ongoing program is backed by the met een missie Netherlands which entered the second period for one year in the future, in the first one-year period that was completed in November 2013 then, the ECPAT entrance unit has made SOP, leaflet and factsheet. Socialization regarding ECPAT Indonesia's legal Services unit; Mentoring several victims; Network meetings, and an audience effort with POLRI and several other related institutions. So far, ECPAT local Unit has successfully handled 8 cases in the areas of Jakarta, Bali, and Palembang and has also successfully made an MoU with POLDA, POLRES, and Kanit PPA Mabes Polri.

The second period is more focused on legal protection for victims of sexual exploitation to the child and advocacy of legal harmonization in the field of child sexual exploitation following the optionally the Protocol of the Children's Rights Convention on the sale of children, child pornography and child prostitution and the enhancement of the ability and capacity of law enforcement in addressing cases of child sexual exploitation (ECPAT Indonesia 2013, 4

- Research on reducing child trafficking in Child Fund working area The program lasts for approximately six months from November 2013 April 2013 and supported by a Child Fund. Working in 3 (three) research areas, namely: West Jakarta \& Tangerang; Central Java; and East Nusa Tenggara.

The main activity of the program is collecting primary data from target respondents consists of children who are victims or survivors of human trafficking with various objectives, and collecting primary data from key stakeholders for the issue each the research areas. The entire program aims to capture the child trade situation in the working area of the child Fund and to design a relevant intervention program on the issue that includes prevention, protection, and/or empowerment (ECPAT Indonesia 2013, 5).

- Regional Conference: Legal protection for child victims of sexual exploitation in Southeast Asia 
The conference was held on 23-24 October 2013 at the Mercure Hotel, Nusa Dua Bali, for the cooperation of ECPAT Indonesia with the French Embassy for Indonesia and supported by the loyal partner ECPAT. The conference aims to establish a partnership in the legal system of Asia Tenggara, which has not yet implemented protection for victims of child sexual exploitation and to recognize and well the legal system that has applied protection for victims of child sexual exploitation. The event attended by 19 participants from 10 countries and 19 speakers who filled this conference in six panels. Along with the meeting also held a photo exhibition of the Romanian Photographer, Alexandra Radu, amounting to 30 photographs that photograph the lives of girls who get trapped in prostitution in Indramayu, Jakarta, Bandung, and Surabaya.

As a follow-up to this conference, ECPAT Indonesia held a "legal protection Workshop for the Children of sexual exploitation victims" held at Adhiyana Auditorium, Wisma Antara on 17 December 2013, with 30 participants aiming to discuss the results of the conference in Bali with critical stakeholders and compile follow-up plans and formulate the measures of entirely from the recommendations generated in the conference in Bali. This event was opened by Ali Khasan, as the representative of the State Minister of Women Empowerment (MENEG PP) and filled by Ahmad Sofyan from ECPAT Indonesia, Cahyani suryanfrom, SH, MH from KEMENKUMHAM, and Katarina Indrayani from Mabes Polri (ECPAT Indonesia 2013, 6).

- Establishment of young people's organization to strengthen youth advocacy and participation

After the success of forming a young organization named KOMPAK Jakarta in 2010 years ago, ECPAT Indonesia generalizes the second generation for KOMPAK Jakarta II, which officially established on 14 September 2013 at the University of Indonesia supported by ECPAT International.

KOMPAK Jakarta II consists of 12 young people composed of 7 men and five women with the head of Derry Fahrizal from Universitas Indonesia. Before being appointed, they were given a supply of trafficking AND ESKA from ECPAT HIMSELF AND from ECPAT members. On 16 November 2013, Ahmad Sofyan, as the national coordinator of ECPAT, gave material on commercial sexual exploitation of children and formed the management of KOMPAK Jakarta II. After being formed, KOMPAK member Jakarta II conducted a BBH to several ECPAT members to gain knowledge on trafficking and ESKA as well as introductions to ECPAT members such as Ykai and Bandungwangi which gets held on 9 December 2013, as well as Kpai on 19 December 2013 (ECPAT Indonesia 2013, 8).

- Dissemination of ECPAT Indonesia's activities through social media and official Web of ECPAT Indonesia

ECPAT Indonesia conducts the dissemination of activities through the official web of ECPAT Indonesia and social media such as Facebook and Twitter. All social media was created in 2012, then. Facebook, for now, has reached 264 people, while Twitter reaches 284 followers. 
While this newsletter uses the Indonesian language, but in December will be made two languages that are Bahasa Indonesia and English. ECPAT also created a newsletter during the year 2013 that gets disseminated through the web, social media, and mailing. The newsletter itself has entered the 8th edition of December 2013, where the newsletter began in April 2013 (ECPAT Indonesia 2013, 9).

ECPAT Indonesia has implemented several programs during the years 2014 up to 2016 to fulfill the objectives following the vision and mission. The following are activities that have been conducted by ECPAT Indonesia from 2014 until 2016:

- Policy advocacy and legal harmonization of the sexual exploitation of children in Indonesia.

This program focuses on the process of improving the status of ratification through public studies and tests to improve the condition of KHA from Presidential Decree No. 36 the year 1996 to act number II the year 2012, here ECPAT more proactive and constructive in the preparation and monitoring of the implementation of RAN ESKA.

Supporting the increased status of the children's Rights convention from Presidential Decree to law, in this case, ECPAT and its members are involved in realizing KHA into LAW. ECPAT's advocacy finally encouraged the acceleration of revision of child protection laws and other laws, including the establishment of each PERDA that is relevant to child sexual exploitation. Review of the Child Protection Act and effort to form the relevant PERDA by ensuring the guarantee of protection of victims, especially the components of restitution, compensation, and rehabilitation. Increased legislation is supported by ensuring the budget for victims of child sexual exploitation in the STATE budget and APBD. The birth of a national action plan for the elimination of child sexual exploitation at a higher level (Keppres) becomes a sustainable budget. The advocacy Model is a must-improve, both in the central and in the region continually. ECPAT Indonesia has a model of advocacy at the national and provincial levels (ECPAT Indonesia 2016).

- Build public awareness to remove requests against child sexual exploitation.

Activities on this program refer to the formulation of IT-based and conventional strategies to build public awareness, develop guidelines and instruments to prevent sexual exploitation of child sex users, develop skills and IT-based literacy and standard for child protection, and cooperate with various sectors of tourism and recreation industry in promoting the prevention of child sex use.

Develop guidelines and instruments in preventing sexual exploitation at the child sex user level. ECPAT Indonesia developed it in the efforts of preventing child sexual exploitation campaigns. Building partnerships with various sectors is essential in the efforts to campaign for ESKA prevention. ECPAT has successfully established cooperation with the tourism and recreation industry sectors that are in contact with child sexual exploitation. 
IT and Conventional-based strategies need to build public awareness. There are formulas and tools in using ECPAT information technology in the future in preventing online sexual exploitation of children. ECPAT Indonesia also includes programs and devices to help children, teachers, and parents. Young people's participation in ESKA is a long-term program developed, more and more young people who care and actively participate in the elimination of ESKA will be better (ECPAT Indonesia 2016).

- It is encouraging the creation of an integrated mechanism with human rights in enhancing the optional implementation of the Child Rights Convention Protocol on the sale of children, prostitution, and pornographic children.

The main activity of the program is encouraging Governments to implement the contents of the Optional Protocol immediately and compile an alternative report for clusters of 8 (eight) of civil society. With this program, ECPAT Indonesia And Its partners successfully Compiled an optional Implementation monitoring group of protocols. Compiled a cluster of 8 reports and addressed the report to the civil society and the UN Child Rights Committee (ECPAT Indonesia, 2016). The group here meant to be part of the children's rights Convention, the steps for special protection (Baperlitbang Kendal 2016).

\section{Conclusions and recommendations}

\subsection{Conclusions}

Child commercial sexual exploitation is an alarming issue. The impact inflicted on victims is a matter of psychic trauma, injuries in the body, and their future destruction as the nation's successor. Their childhood should get filled with play and education, but what happens is sexual exploitation.

ECPAT Indonesia is committed to strengthening national action to prevent and eliminate the ESKA in Indonesia by establishing collaboration with key cross-sector parties such as civil society organizations, academics, government agencies, the private sector, international agencies, and other relevant sectors. Our presence is to ensure that all elements of society, especially the government, perform serious and earnest measures in dealing with this crime.

The efforts and roles undertaken by ECPAT as an international organization are in line with the government of Indonesia. It can get viewed from the cooperation between the two actors. ECPAT helps handle the ESKA as a problem that occurs in Indonesia with various methods. Advocacy to the government, collaboration with multiple sectors also approaches the community is part of the activities conducted in the vulnerable time from 2011 up to 2015.

Cooperation with the Government of Indonesia looks good with many government agencies that join. Ministry of Tourism, Mabes Polri, Ministry of Social Affairs, Mahkama Agung, and PERADI. Cooperation conducted in the form of planning law, training of police members, protection for the victims of ESKA until the MOU.

Proving that international relations actors nowadays no longer only focus on the country or $g$ to $\mathrm{G}$, but rather other actors can play in international relations. In addition to the global issue which was growing, no longer only fixed in security or high political but low political matters such as culture can also attract and influence other interests. 


\subsection{Recommendations}

- We recommend that practitioners of international relations do not perceive the role of international organizations in the eyes because this research can prove that international organizations can influence a country's policy on a problem.

- People should understand that the ESKA case in Indonesia is a serious problem. People should be able to know the factors that lubricated the event of ESKA and how ECPAT role as an international organization. With this, more discuss the importance of the role of international organizations in addressing problems occurring in a country. 


\section{BIBLIOGRAPHY}

\section{Book}

Bennet, A Le Roy. 1995. International Organization. London: George Allen and Unwin Publisher Company.

Bogdan, Robert, and Taylor, Steven. 1975. Introduction to Qualitative Research for Education: An Introduction to Theory and Methods. New York: John Willey.

Hasan, M Iqbal. 2002. Fundamentals of material research methodology and its application. Bogor: ghalia, Indonesia.

Hermawan, Yulius, P., 2007. Transformation in International relations studies: actors, issues, and methodologies. Yogyakarta: Graha Ilmu.

National Coalition for the elimination of commercial sexual exploitation children. 2008. International Instrument on child protection from the dangers of commercial sexual exploitation. Medan: Cerana Production.

Mingst, Karen. 1999. Essentials of International Relations. New York: w. W Norton \& Company.

Moong, Lexy, J., 2004. Qualitative Research Methods. Bandung: Juvenile Rosdakarya.

Mulyana, Deddy. 2001. Methodology Qualitative research. Bandung: PT. Adolescent Rosdakarya.

Reus Smith, Christian. 2001. constructivism. In Scott Burchill, Theories of International Relations. New York: Palgrave.

Rudy, Teuku of May. 2009. administration of \& International organization. Bandung: Refiak Aditama.

Sevilla, Consuelo, G., 1993. Introduction to research methods. Jakarta: UI Press.

Peter, Sumaryosuryokusumu. 1997. Case studies of international organizations. Bandung: Alumni.

Sutopo, H.B., 2002. Qualitative Research methodology. Surakarta: Eleven March University Press.

Usman, Husaini and Akbar, Purnomo. 1996. social Research methodology. Jakarta: PT. Bumi Aksara.

Journals and articles :

Ambarsari, yeny Novita. 2017. The perspective of neorealism in International relations theory . Retrieved 15 September 2017. http://yeny-novita-ambarsarifisip16.web.unair.ac.id/artikel_detail-171698-theory\% 20RELATIONSHIP\% 20INTERNATIONAL $\%$ 20SOH $\% 20 \% 20201 \% 20$ (journal)-perspective $\%$ 20Neorealism\% 20in\% 20Theory\% 20Link\% 20international. html

ECPAT, 1996. "Declaration and Agenda for Action 1st World Congress Against Commercial Sexual Study of Children”. Retrieved 15 May 2017. http://www.ecpat.org/wpcontent/uploads/legacy/stockholm_declaration_1996.pdf

And Purwono, Andi. 2010. Constructivism in International relations Studies: theoretical ideas and positions Teoritik. Vol. 7 No. 2, Oct. 2014. Retrieved 2 June 2017. https://publikasiilmiah.unwahas.ac.id/index.php/SPEKTRUM/article/view/485

Rafiqa, Adni Luthfi. 2015. The role of End Child Prostitution, Child Pornography And Trafficking of Children For Sexual Purposes (ECPAT) in addressing the case of 
child Trafficking in Albania (2007-2012). Online student Journal. Volume. 2 No. 1 October 2015. In Access on 21 March 2017. https://jom.unri.ac.id/index.php/JOMFISIP/article/viewFile/7070/675

\section{Report}

Department of State. 2011. Trafficking in Person Report. USA: Department of state.

ECPAT, 2011. ECPAT Indonesia Annual Report Year 2009-2011. Jakarta: ECPAT Indonesia.

ECPAT, 2012. ECPAT Indonesia Annual report in 2012. Jakarta: ECPAT Indonesia.

ECPAT, 2013. ECPAT Indonesia Annual report in 2013. Jakarta: ECPAT Indonesia.

Helga Konrad, Trafficking In Human Beings - The Ugly Face of Europe, European Conference on Preventing and combating Trafficking In Human Beings Global Challenge for The 21st Century, Brussels, Belgium, September 2002.

Rafiqa, Adni Luthfi. 2015. The role of End Child Prostitution, Child Pornography And Trafficking of Children For Sexual Purposes (ECPAT) in addressing the case of child Trafficking in Albania (2007-2012). Online student Journal. Volume. 2 No. 1 October 2015. In Access on 21 March 2017. https://jom.unri.ac.id/index.php/JOMFISIP/article/viewFile/7070/675

\section{Internet}

Baperlitbang Kendal. Ibn. 2016. "Convention on the Rights of children." Retrieved 25 June 2017. http://baperlitbang.kendalkab.go.id/info-terkini/87-konvensi-hakhak-anak-kha.html

ECPAT Indonesia. 2016. "About us: who we are." Retrieved 19 May 2017. http://ecpatindonesia.org/tentang-kami/

ECPAT Indonesia. 2016. Strategic objectives 2014 - 2016: Main Activities, strategy, and results. Retrieved 24 June 2017. http://ecpatindonesia.org/aksi-kami/

ECPAT International. 2016. "At the Forefront of the Fight Against Sexual exploitation of Children for the Past 25 Year". Retrieved 13 May 2017. http://www.ecpat.org/about-ecpat/

ECPAT International. 2016. "Welcome TO ECPAT." Retrieved 20 May 2017. http://www.ecpat.org/

\section{Interview}

The interview activity done with Mr. Andy Ardian as the Manager of the Program at the ECPAT Indonesia secretariat located in Kalibata Indah lobbies U23, Jl. Rawajati Timur, Pancoran-South Jakarta on Tuesday, 05 June 2017. 